\title{
PENGEMBANGAN SSP FISIKA BERBASIS PENDEKATAN CTL UNTUK MENINGKATKAN KETERAMPILAN PROSES SAINS DAN MOTIVASI BELAJAR
}

\author{
Faiq Makhdum Noor ${ }^{1)}$, Insih Wilujeng ${ }^{2)}$ \\ Prodi Pendidikan Sains PPs UNY ${ }^{1)}$, Universitas Negeri Yogyakarta ${ }^{2)}$ \\ faiq_putra@yahoo.com ${ }^{1)}$, insihuny@yahoo.co.id ${ }^{2)}$
}

\begin{abstract}
Abstrak
Penelitian ini bertujuan untuk menghasilkan Subject-Specific Pedagogy (SSP) fisika, untuk meningkatkan keterampilan proses sains dan motivasi belajar siswa. Penelitian ini menggunakan model pengembangan 4D. Subjek coba pada penelitian ini merupakan siswa SMA Muhammadiyah 2 Yogyakarta kelas XI. Instrumen pengumpulan data berupa lembar validasi ahli, lembar observasi keterampilan proses sains, lembar observasi keterlaksanaan pembelajaran, angket respon siswa terhadap buku siswa dan LKS, angket respon siswa terhadap proses pembelajaran, angket motivasi belajar siswa, dan soal tes keterampilan proses sains. Data penelitian ini dikumpulkan melalui lembar observasi, angket, dan soal tes tertulis. Data yang diperoleh dianalisis secara kuantitatif. Hasil penelitian menunjukkan bahwa (1) pengembangan SSP fisika dilaksanakan sesuai dengan prosedur pengembangan produk. (2) hasil validasi ahli menunjukkan bahwa SSP fisika berkriteria sangat baik. (3) keterbacaan buku siswa dan LKS berkriteria baik. (4) kenaikan skor kelas eksperimen lebih tinggi dari kelas kontrol dalam aspek keterampilan proses sains dan motivasi belajar siswa. Hasil tersebut menunjukkan bahwa SSP fisika ini layak digunakan dalam pembelajaran.
\end{abstract}

Kata Kunci: SSP fisika, pendekatan CTL, KPS, motivasi belajar

\section{DEVELOPING THE SSP OF PHYSICS BASED ON THE CTL APPROACH TO IMPROVE THE SCIENCE PROCESS SKILLS AND LEARNING MOTIVATION}

\begin{abstract}
This research aims to develop a learning device as Subject-Specific Pedagogy (SSP) of physics, and to improve science process skills and learning motivation of the students. This research used the $4 D$ model. The subjects of this research were the XI grade students of Muhammadiyah High School 2 Yogyakarta. The data collecting instruments were expert validation sheets, science process skill observation sheets, questionnaire of students' response to the student books and worksheets, questionnaire of students' response to teaching process, students' motivation learning sheets, and science process skill paper test. The research data were collected through observation, questionnaire, and paper test, and analyzed quantitatively. The results show as follows. (1) The development of physics SSP is carried out in accordance with the procedures of 4D model product development. (2) The results of expert's validation show the physics SSP is in the very good criteria. (3) The readability of the student books and worksheets is in the good criteria. (4) The increasing of the score of science process skills and students' learning motivation in the experimental class is higher than that in the control class. This shows that the physics SSP is fit for use in physics teaching.
\end{abstract}

Key words: SSP of physics, CTL approach, SPS, learning motivation 


\section{PENDAHULUAN}

Badan Standar Nasional Pendidikan (BSNP, 2007, p.16) menegaskan tentang standar penilaian pendidikan bahwa hasil Ujian Nasional digunakan sebagai salah satu pertimbangan untuk penentuan kelulusan siswa dari program dan/atau satuan pendidikan. Ujian Nasional lebih menekankan pada aspek kognitif, sehingga guru harus memperhatikan aspek lain, misalnya aspek keterampilan proses sains, motivasi belajar, serta sikap ilmiah. Wilke (2005, p.539) menyimpulkan bahwa terdapat keuntungan potensial dalam pembelajaran keterampilan proses sains, antara lain dapat meningkatkan keterampilan proses yang harus dimiliki siswa selama pembelajaran.

Data kuantitatif yang diterbitkan oleh Programe for International Student Assessment (PISA) tahun 2009 menunjukkan bahwa Indonesia menduduki peringkat ke-60 dari 65 negara peserta dalam bidang literasi sains. Pendekatan pembelajaran yang inovatif dapat digunakan sebagai solusi dalam mengembangkan literasi sains siswa dan juga kemampuan siswa baik dari aspek kognitif, afektif, maupun psikomotorik. Salah satu pendekatan pembelajaran inovatif, yaitu pendekatan contextual teaching and learning (CTL) atau disebut juga pendekatan kontekstual. Pendekatan kontekstual memiliki tujuh komponen utama, yaitu konstruktivisme (costructivism), menemukan (inquiry), bertanya (questioning), masyarakat belajar (learning community), pemodelan (modeling), refleksi (reflection), dan penilaian yang sebenarnya (authentic assessment) (Depdiknas, 2002, p.10).

Pendekatan kontekstual merupakan pendekatan pembelajaran yang dapat memacu motivasi belajar siswa. Riecher (2001, p.4) mengungkapkan bahwa pembelajaran kontekstual mengandung esensi pengalaman belajar siswa untuk dapat meningkatkan motivasi ketertarikan siswa, belajar, dan rasa percaya diri. Motivasi belajar mempunyai fungsi yang penting, yaitu sebagai pendorong, pengarah dan penggerak tingkah laku. Hamalik (2011, p.107) mengungkapkan terdapat 2 komponen motivasi, yaitu komponen dalam (inner component) dan kom- ponen luar (outer component). Komponen dalam merupakan perubahan pada diri seseorang, rasa ketidakpuasan, ataupun ketegangan psikologis. Komponen luar terkait dengan tujuan yang ingin dicapai.

Hakikat motivasi belajar merupakan dorongan internal dan eksternal pada siswa yang sedang belajar untuk mengadakan perubahan tingkah laku dengan indikator atau unsur yang mendukung. Indikator motivasi belajar (Uno, 2011, p.23) dapat diklasifikasikan sebagai (1) adanya hasrat dan keinginan berhasil, (2) adanya dorongan dan kebutuhan dalam belajar, (3) adanya harapan dan cita-cita masa depan, (4) adanya penghargaan dalam belajar, (5) adanya kegiatan yang menarik dalam belajar, serta (6) adanya lingkungan belajar yang kondusif, sehingga memungkinkan siswa dapat belajar dengan baik.

Guru dituntut untuk memiliki kemampuan mengajar (pedagogy) sekaligus kemampuan penguasaan materi pelajaran (content) yang baik agar siswa dapat mengikuti pelajaran dengan menyenangkan. Kemampuan guru dalam merancang dan melaksanakan pembelajaran sangat terkait dengan kemampuan pedagogical content knowledge (PCK) yang dimiliki guru. Shulman (Ball, 2008, p.389) menyatakan bahwa domain khusus dari pengetahuan mengajar guru terdapat pada kemampuan guru dalam pedagogical content knowledge. PCK menjembatani antara penguasaan materi dengan kemampuan mengajar. Berdasarkan latar belakang tersebut, penting dilakukan penelitian tentang pengembangan SSP fisika berbasis pendekatan CTL untuk meningkatkan keterampilan proses sains dan motivasi belajar siswa.

\section{METODE}

Penelitian ini termasuk dalam jenis penelitian pengembangan. Model pengembangan yang digunakan dalam penelitian ini adalah 4-D yang dikembangkan oleh Thiagarajan, dkk (1974, p.5). Model pengembangan 4D terdiri atas 4 tahap utama, yaitu: (1) define (pendifinisian), (2) design (perancangan), (3) develop (pengembangan), serta (4) disseminate (penyebaran). Penelitian ini hanya terbatas sampai dengan tahap develop. 


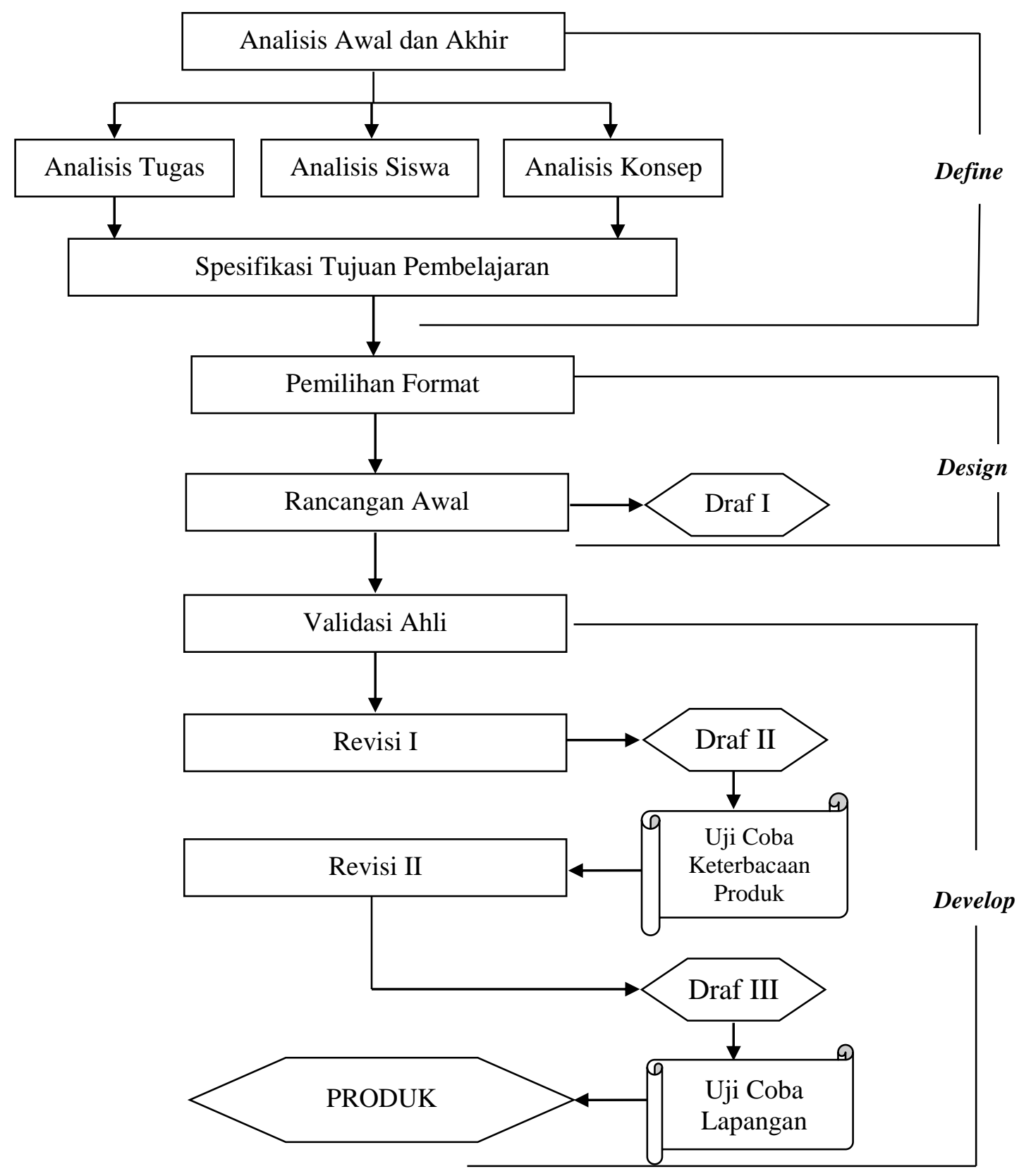

Gambar 1. Langkah Penelitian Model 4-D (diadaptasi dari Thiagarajan dkk, 1974, p.5)

Keterangan Gambar 1

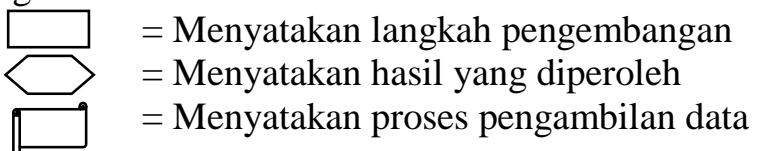

Penelitian ini dilakukan pada saat proses pembelajaran materi fluida semester genap tahun akademik (TA) 2012/2013 di SMA Muhammadiyah 2 Yogyakarta. Subjek uji penelitian ini merupakan siswa kelas XI IPA SMA Muhammadiyah 2 Yogyakarta Semester 2. Subjek uji coba keterbacaan produk terdiri dari 10 orang peserta didik kelas XI IPA 3 dan subjek uji coba lapangan terdiri dari 36 peserta didik kelas XI
IPA1 (KK), serta 36 peserta didik kelas XI IPA 5 (KE).

Desain uji coba terdiri dari dua tahap, yaitu uji coba keterbacaan produk dan uji coba lapangan. Uji coba keterbacaan produk dilakukan untuk melihat keterbacaan produk yang berupa Buku Siswa dan Lembar Kerja Siswa (LKS) (draf II) oleh 10 siswa kelas XI. Hasil yang diperoleh dari uji coba keterbacaan produk digunakan untuk melaksanakan uji coba lapang- 
an. Desain uji coba lapangan menggunakan control-group pretest posttest design. metode quasi eksperimen dengan rancangan

Tabel 1. Desain Penelitian Control-Group Pre-Test Post-Test Design

\begin{tabular}{cccc}
\hline Group & Pre-Test & Treatment & Post-Test \\
\hline KK & $\mathrm{T}_{1}$ & $\mathrm{X}_{\mathrm{a}}$ & $\mathrm{T}_{2}$ \\
$\mathrm{KE}$ & $\mathrm{T}_{1}$ & $\mathrm{X}_{\mathrm{b}}$ & $\mathrm{T}_{2}$ \\
\hline
\end{tabular}

Tes awal (pretest) diberikan di awal pembelajaran kepada siswa kelas eksperimen (KE) maupun kelas kontrol (KK) berupa tes pilihan ganda dan uraian keterampilan proses sains. Selama proses pembelajaran berlangsung, dilakukan observasi mengenai keterampilan proses sains. Observasi keterampilan proses sains dilakukan dengan meminta bantuan 3 observer yang telah diberi pengarahan sebelumnya untuk melihat keterampilan proses sains siswa. Lembar observasi keterampilan proses sains berupa susunan pernyataan tentang keterampilan proses sains yang kemudian diambil skornya. Setelah diberikan tes awal, siswa pada kelas eksperimen diberikan perlakuan berupa SSP fisika berbasis pendekatan kontekstual. Siswa pada kelas kontrol diajar dengan perangkat pembelajaran fisika yang biasa diterapkan di kelas. Pada akhir pembelajaran, dilakukan tes akhir (posttest).
Keterampilan proses sains siswa pada saat posttest diukur dengan lembar instru-men yang setara dengan lembar instrumen pada saat pretest. Selain itu, pada akhir pembelajaran juga diberi angket motivasi belajar siswa.

Instrumen pengumpulan data berupa lembar validasi ahli, lembar observasi keterampilan proses sains, lembar observasi keterlaksanaan pembelajaran, angket respon siswa terhadap buku siswa dan LKS, angket respon siswa terhadap proses pembelajaran, angket motivasi belajar siswa, dan soal tes keterampilan proses sains.

Langkah yang digunakan untuk menganalisis data, yaitu (a) tabulasi semua data yang diperoleh untuk setiap aspek dari butir penilaian yang tersedia dalam instrumen; (b) total skor yang diperoleh dikonversikan dalam bentuk data kualitatif skala lima sesuai Tabel 2.

Tabel. 2. Konversi Data Kuantitatif Menjadi Data Kualitatif dengan Skala Lima

\begin{tabular}{ccc}
\hline Interval & Kriteria & Nilai \\
\hline $\mathrm{X}>M_{\mathrm{i}}+1.5 \mathrm{SD}_{\mathrm{i}}$ & Sangat Baik & $\mathrm{A}$ \\
$M_{\mathrm{i}}+\mathrm{SD}_{\mathrm{i}}<\mathrm{X} \leq M_{\mathrm{i}}+1.5 \mathrm{SD}_{\mathrm{i}}$ & Baik & $\mathrm{B}$ \\
$M_{\mathrm{i}}-0.5 \mathrm{SD}_{\mathrm{i}}<\mathrm{X} \leq M_{\mathrm{i}}+\mathrm{SD}_{\mathrm{i}}$ & Cukup Baik & $\mathrm{C}$ \\
$M_{\mathrm{i}}-1.5 \mathrm{SD}_{\mathrm{i}}<\mathrm{X} \leq M_{\mathrm{i}}-0.5 \mathrm{SD}_{\mathrm{i}}$ & Kurang Baik & $\mathrm{D}$ \\
$\mathrm{X} \leq M_{\mathrm{i}}-1.5 \mathrm{SD}_{\mathrm{i}}$ & Sangat Kurang Baik & $\mathrm{E}$ \\
\hline
\end{tabular}

(Azwar, 2011, p.163)

\section{Analisis Kevalidan SSP Fisika}

SSP fisika yang telah dikembangkan dianalisis berdasarkan kriteria yang terdapat pada Tabel 2. Hasil validasi kemudian dikonversi ke dalam skala 5. SSP fisika diklasifikasikan valid apabila tingkat validitas minimal yang dicapai adalah baik.

\section{Analisis Keterbacaan Buku Siswa dan LKS}

Buku siswa dan LKS dievaluasi tingkat keterbacaannya oleh siswa sebelum digunakan dalam uji coba lapangan. Data mengenai keterbacaan buku siswa dan LKS dianalisis berdasarkan kriteria seperti pada Tabel 2. Buku siswa dan LKS dinyatakan dapat terbaca oleh siswa jika kriteria minimal yang dicapai adalah baik.

\section{Analisis keterlaksanaan pembelajaran}

Penilaian keterlaksanaan fase pembelajaran dalam RPP dilakukan oleh seorang observer. Kriteria setiap fase dalam sintaks yang dimaksud adalah terlaksana dan tidak terlaksana. Keterlaksanaan RPP dianalisis berdasarkan kriteria seperti pada Tabel 2. Proses pembelajaran dikategorikan telah terlaksana jika kriteria minimal yang dicapai adalah baik.

\section{Analisis Uji Empirik Soal KPS}

Uji empirik soal KPS terdiri dari uji validitas dan reliabilitas terhadap soal pilihan ganda dan uraian. Uji validitas menggunakan korelasi product moment, sedangkan reliabilitas menggunakan cronbach alpha. Uji emperik dilakukan 
dengan bantuan program SPSS 16.0 for windows.

\section{Ketercapaian Keterampilan Proses Sains dan Motivasi Belajar}

Prasyarat Analisis

\section{Uji Normalitas}

Uji normalitas digunakan untuk mengetahui sebaran data berdistribusi normal atau tidak. Uji normalitas dilakukan dengan uji One Sample Kolmogorof Smirnov. Persyaratan data berdistribusi normal jika probabilitas atau $\mathrm{p}>$ 0,05 pada uji normalitas Kolmogorof Smirnov.

\section{Uji Homogenitas}

Uji homogenitas digunakan untuk mengetahui homogen atau tidaknya populasi penelitian. Uji homogenitas dilakukan dengan uji homogenitas varians dengan bantuan rogram SPSS 16.0 for windows. Sampel penelitian dapat dikatakan berasal dari populasi yang homogen apabila harga probabilitas perhitungan lebih besar dari 0,05 atau $p>0,05$ pada taraf signifikansi $5 \%$.

\section{Uji Korelasi}

Uji korelasi bertujuan untuk mengetahui ada atau tidaknya hubungan antara keterampilan proses sains dengan motivasi belajar. Uji korelasi dilakukan dengan menggunakan uji Person Correlation. Uji Person Correlation digunakan untuk mengetahui ada atau tidaknya hubungan antara keterampilan proses sains dengan motivasi belajar. Uji korelasi ini dihitung menggunakan program SPSS 16.0 for windows.

Uji Hipotesis

\section{Uji Multivariat}

Hipotesis pada penelitian ini meliputi:

$\mathrm{H}_{01}$ : Pembelajaran fisika dengan SSP berbasis pendekatan contextual teaching and learning tidak lebih baik dibandingkan dengan perangkat pembelajaran konvensional dalam meningkatkan keterampilan proses sains dan motivasi belajar siswa

$\mathrm{Ha}_{1}$ : Pembelajaran fisika dengan SSP berbasis pendekatan contextual teaching and learning lebih baik dibandingkan dengan perangkat pembelajaran konvensional untuk me- ningkatkan keterampilan proses sains dan motivasi belajar siswa

Untuk menjawab hipotesis tersebut dilakukan dengan menggunakan uji multivariat dengan bantuan program SPSS 16.0 for windows. Ghozali (2011, p.90) menyatakan bahwa uji multivariat dilihat berdasarkan Hotelling's Trace pada output multivariate test. Kriteria pengujiannya adalah $\mathrm{H}_{01}$ ditolak jika $\mathrm{F}_{\text {hitung }} \geq$ $\mathrm{F}\left((\alpha) ;(\mathrm{p}):\left(\mathrm{n}_{1}+\mathrm{n}_{2}-\mathrm{p}-1\right)\right)$ atau angka signifikansi (probabilitas) yang dihasilkan $<0.05$.

Penelitian ini memiliki hipotesis berikut.

$\mathrm{H}_{02}$ : Pembelajaran fisika dengan SSP berbasis pendekatan contextual teaching and learning tidak lebih berpengaruh dibandingkan dengan perangkat pembelajaran konvensional terhadap keterampilan proses sains siswa.

$\mathrm{H}_{\mathrm{a} 2}$ : Pembelajaran fisika dengan SSP berbasis pendekatan contextual teaching and learning lebih berpengaruh dibandingkan dengan perangkat pembelajaran konvensional terhadap keterampilan proses sains siswa.

$\mathrm{H}_{03}$ : Pembelajaran fisika dengan SSP berbasis pendekatan contextual teaching and learning tidak lebih berpengaruh dibandingkan dengan perangkat pembelajaran konvensional terhadap motivasi belajar.

$\mathrm{H}_{\mathrm{a} 3}$ : Pembelajaran fisika dengan SSP berbasis pendekatan contextual teaching and learning lebih berpengaruh dibandingkan dengan perangkat pembelajaran konvensional terhadap motivasi belajar.

\section{HASIL DAN PEMBAHASAN}

\section{Hasil Validasi Silabus}

Berdasarkan hasil validasi terhadap silabus untuk setiap aspek diperoleh data antara lain aspek format dengan skor 3,83 berkategori baik, aspek perumusan indikator dengan skor 3,67 berkategori baik, aspek alokasi waktu dengan skor 3,50 berkategori baik, aspek sumber belajar dengan skor 3,67 berkategori baik, serta aspek penilaian dengan skor 4 dengan kategori sangat baik. Berdasarkan data tersebut dapat disimpulkan bahwa silabus yang telah dikembangkan layak untuk digunakan, karena telah memenuhi standar minimal penggunaan silabus, yaitu berkategori baik. Hasil validasi silabus disajikan pada Gambar 2. 


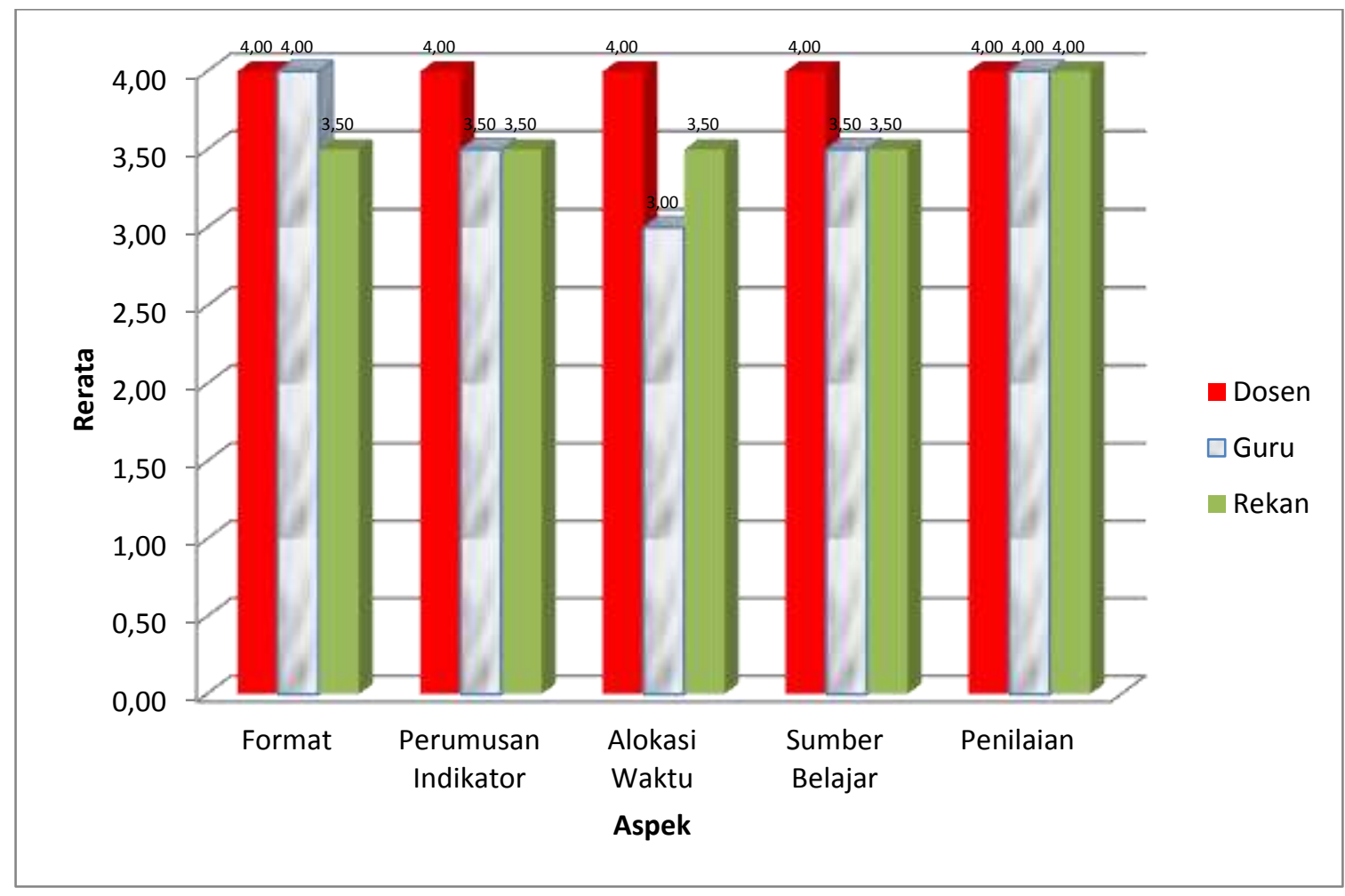

Gambar 1. Diagram Hasil Validasi Silabus

\section{Hasil Validasi RPP}

Hasil validasi RPP untuk setiap aspek diperoleh hasil bahwa aspek identitas pelajaran memiliki skor 4,33 dengan kategori sangat baik, aspek capaian kompetensi memiliki skor 4,00 dengan kategori sangat baik, aspek materi pembelajaran memiliki skor 3,67 dengan kategori baik, aspek alokasi waktu memiliki skor 3,50 dengan kategori baik, aspek pendekatan pembelajaran memperoleh skor 3,44 dengan kategori baik, aspek kegiatan pembelajaran memperoleh skor 3,56 dengan kategori sangat baik, aspek pemilihan sumber belajar memperoleh skor 3,58 dengan kategori sangat baik, aspek penilaian hasil belajar memperoleh skor 3,67 dengan kategori sangat baik, aspek kebahasaan memperoleh skor 3,67 dengan kategori sangat baik, serta aspek KPS dan motivasi belajar memperoleh skor 3,67 dengan kategori sangat baik. Berdasarkan data tersebut dapat disimpulkan bahwa RPP yang telah dikembangkan layak untuk digunakan dalam pembelajaran, karena telah memenuhi standar minimal dengan kategori baik. Hasil validasi RPP disajikan pada Gambar 3. 


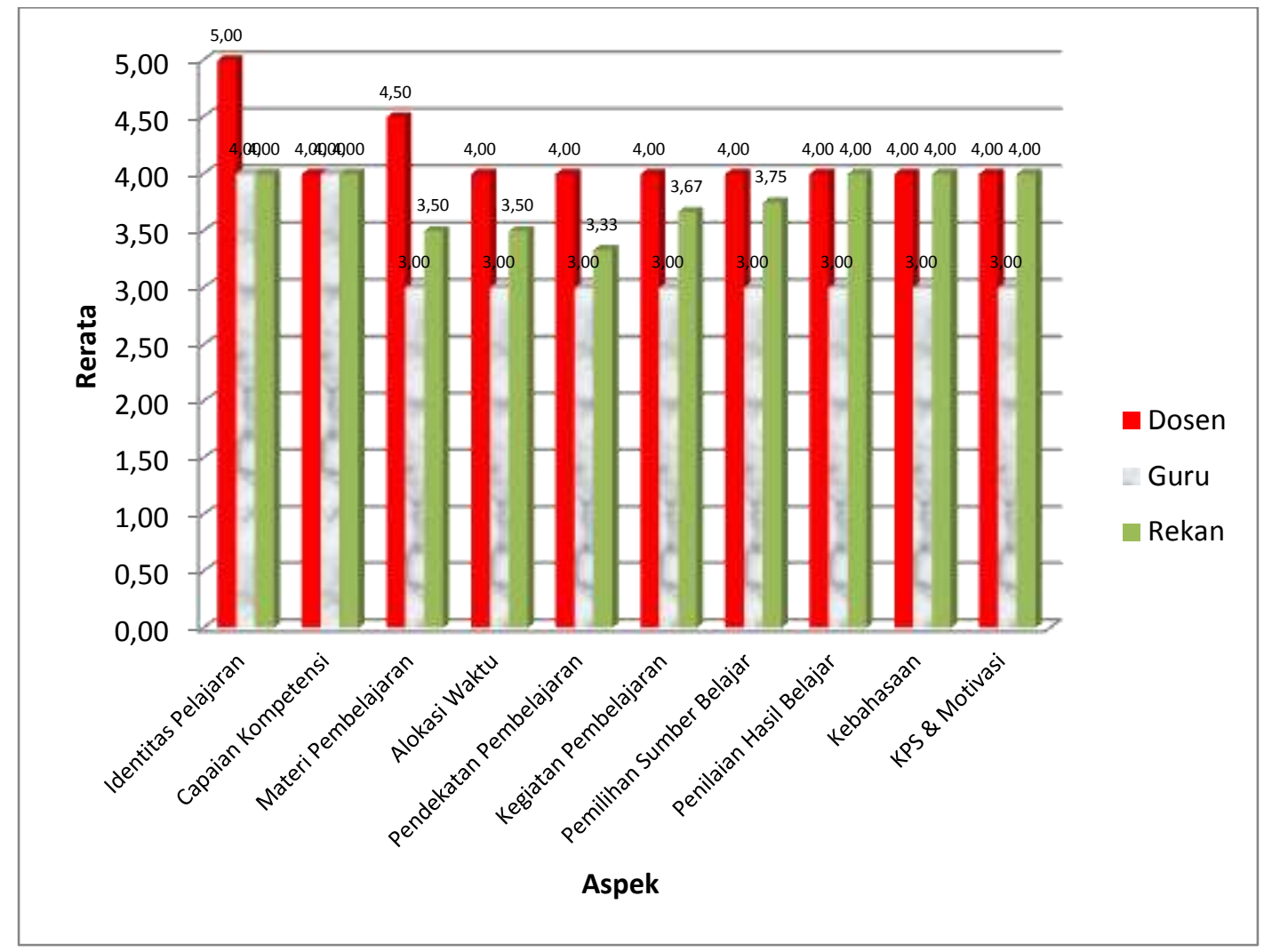

Gambar 3. Diagram Hasil Validasi RPP

\section{Hasil Validasi Buku Siswa}

Hasil validasi buku siswa untuk setiap aspek diperoleh data antara lain untuk aspek materi pembelajaran memperoleh skor 4,17 dengan kategori sangat baik, aspek kebahasaan memperoleh skor 4,67 dengan kategori sangat baik, aspek teknik penyusunan memperoleh skor 3,67 dengan kategori sangat baik, serta aspek KPS dan motivasi belajar memperoleh skor 4,67 dengan kategori sangat baik. Berdasarkan hasil penilaian ini dapat disimpulkan bahwa buku siswa yang telah dikembangkan layak untuk digunakan dalam pembelajaran, karena telah memenuhi standar minimal kualitas buku siswa yaitu berkategori baik. Hasil validasi buku siswa disajikan pada Gambar 4.

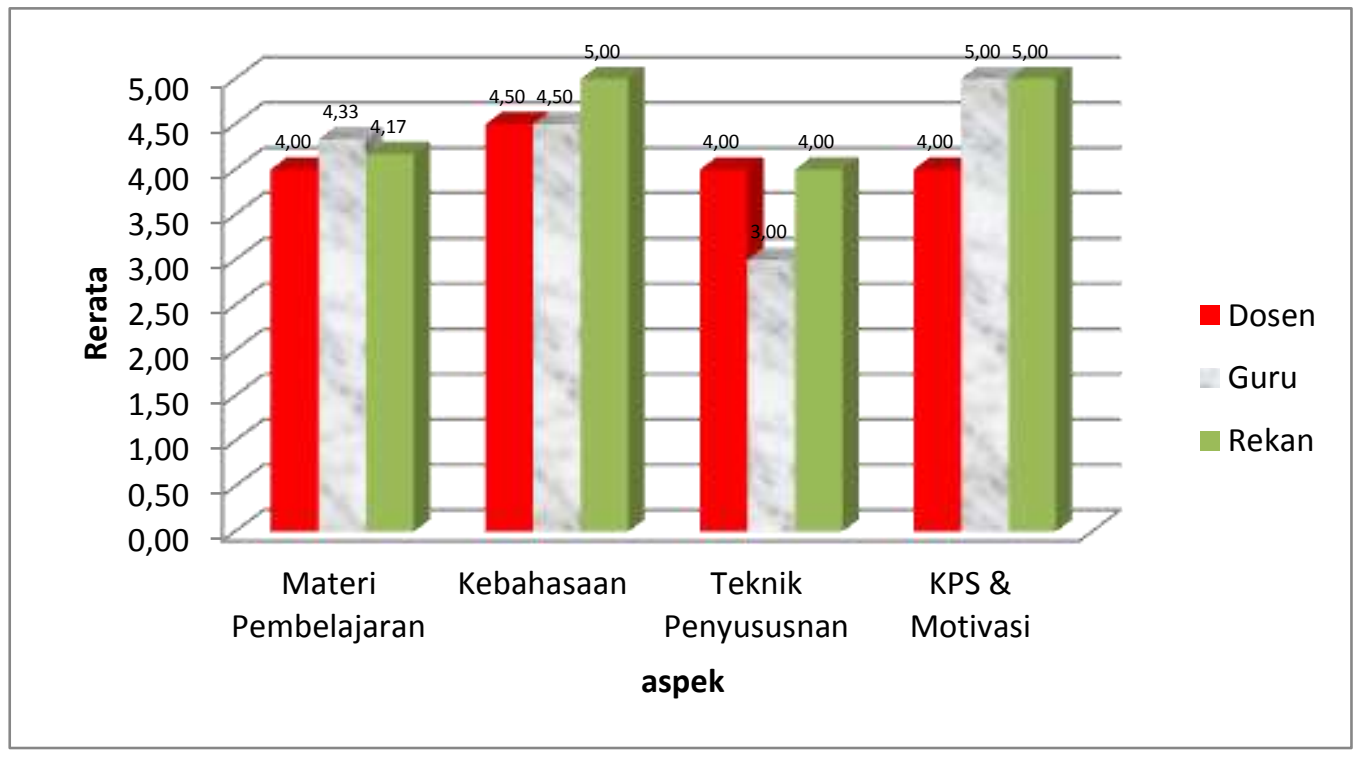

Gambar 4. Diagram Hasil Validasi Buku Siswa 


\section{Hasil Validasi LKS}

Hasil validasi LKS untuk setiap aspek diperoleh hasil antara lain untuk aspek kesesuain materi memperoleh skor 4,17 dengan kategori sangat baik, aspek kesesuaian syarat konstruksi memperoleh skor 4,33 dengan kategori sangat baik, aspek kesesuaian syarat teknis memperoleh skor 3,83 dengan kategori sangat baik, serta aspek KPS dan motivasi belajar memperoleh skor 4 dengan kategori sangat baik. Berdasarkan hasil validasi ini dapat disimpulkan bahwa LKS yang telah dikembangkan layak untuk digunakan untuk proses pembelajaran, karena telah memenuhi standar minimal kualitas LKS, yaitu dengan kategori baik. Hasil validasi LKS disajikan pada Gambar 5.

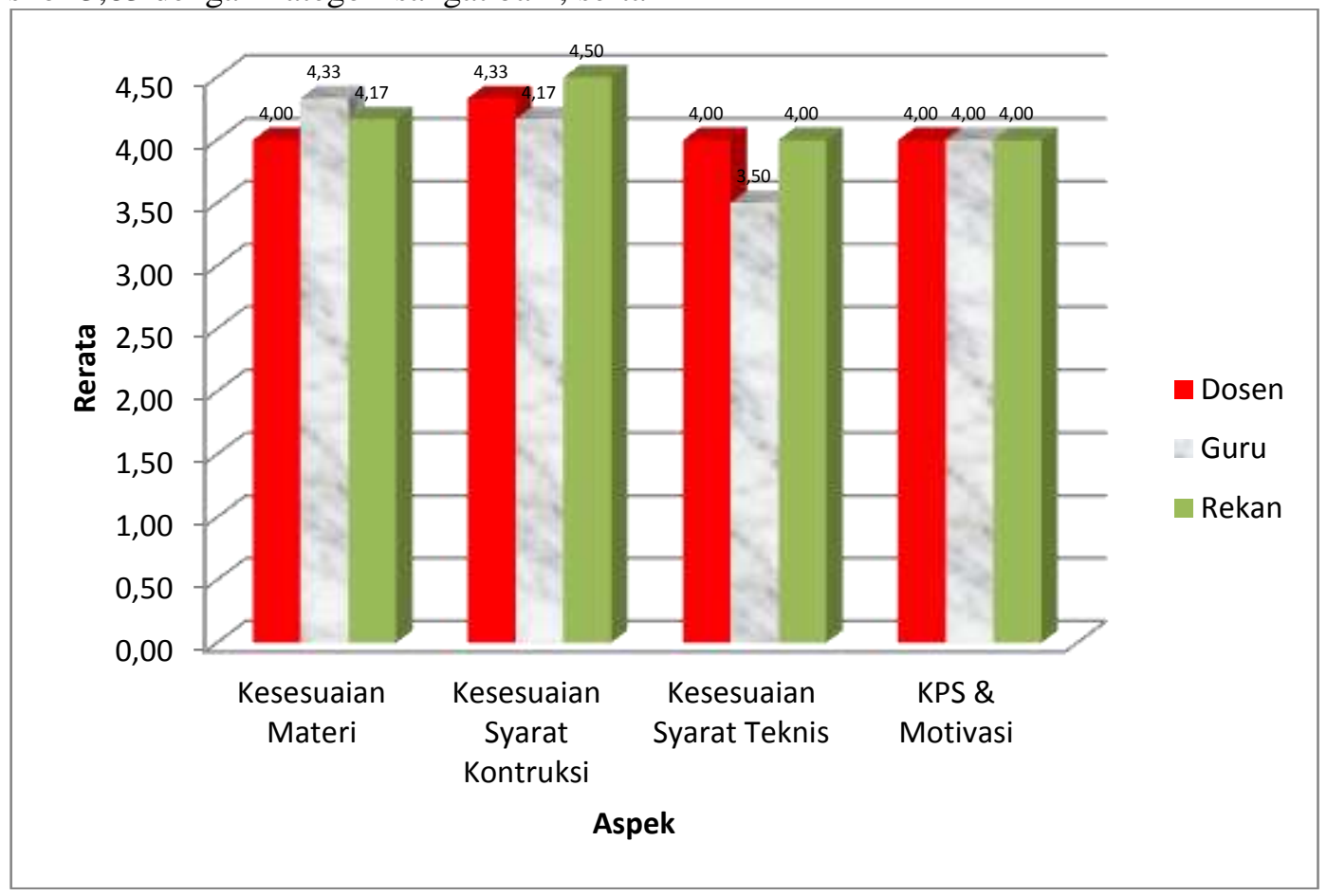

Gambar 5. Diagram Hasil Validasi LKS

\section{Hasil Validasi Instrumen Penilaian}

Instrumen penilaian yang digunakan dalam penelitian ini terdiri dari soal tes KPS, angket motivasi belajar dan lembar observasi KPS. Analisis data hasil validasi instrumen penilaian ini hanya mencakup angket motivasi belajar dan lembar observasi KPS. Soal tes KPS dianalisis tersendiri melalui hasil validasi empiris. Rerata skor validasi instrumen penilaian untuk setiap aspek antara lain aspek KPS dan motivasi belajar memperoleh skor 3,92 dengan kategori sangat baik, aspek konstruksi memperoleh skor 4,11 dengan kategori sangat baik, serta aspek kebahasaan memperoleh skor 3,83 dengan kategori sangat baik. Berdasarkan hasil validasi ini dapat disimpulkan bahwa instrumen penilaian yang telah dikembangkan layak untuk digunakan, karena telah memenuhi standar minimal kualitas LKS, yaitu berkategori baik. Hasil validasi instrumen penilaian disajikan pada Gambar 6.

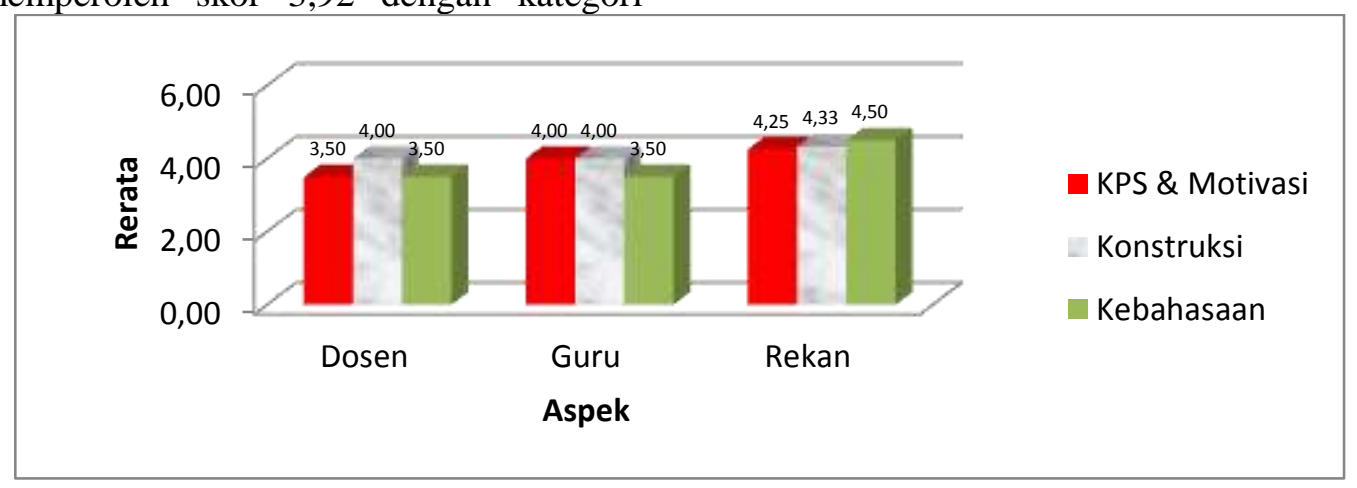

Gambar 6. Diagram Hasil Validasi Instrumen Penilaian 


\section{Hasil Uji Coba Terbatas}

Hasil uji coba terbatas meliputi data uji coba keterbacaan buku siswa dan LKS. Data hasil uji coba keterbacaan buku siswa dan LKS disajikan pada Tabel 6 dan Tabel 7.

Tabel 6. Uji Coba Keterbacaan Buku Siswa

\begin{tabular}{cccc}
\hline No. & Aspek & Rerata & Kategori \\
\hline 1 & Kelayakan Isi & 3,30 & SB \\
2 & Kebahasaan & 3,65 & SB \\
3 & Penyajian & 2,90 & B \\
\hline
\end{tabular}

Tabel 7. Uji Coba Keterbacaan LKS

\begin{tabular}{cccc}
\hline No. & Aspek & Rerata & Kategori \\
\hline 1 & Kelayakan Isi & 3,08 & B \\
2 & Kebahasaan & 3,60 & SB \\
3 & Penyajian & 3,15 & B \\
\hline
\end{tabular}

\section{Hasil Uji Coba Lapangan}

Hasil uji coba lapangan meliputi data pretest, lembar observasi KPS, keterlaksanaan RPP, posttest, dan angket respon siswa.

\section{Hasil Pretest}

Hasil analisis data yang diperoleh dari pretest disajikan pada Tabel 8, Tabel 9, dan Tabel 10.
Tabel 8. Deskriptif Statistik Soal KPS

\begin{tabular}{cccc}
\hline No & Statistik & Eksp. KPS & Kont. KPS \\
\hline 1 & Mean & 62,14 & 61,03 \\
2 & Median & 62,00 & 62,00 \\
3 & Modus & 58,00 & 68,00 \\
4 & Simpangan baku & 8,83 & 8,30 \\
5 & Minimum & 44,00 & 41,00 \\
6 & Maksimum & 79,00 & 79,00 \\
\hline
\end{tabular}

Berdasarkan inforasi pada Tabel 8 terlihat bahwa skor mean untuk kelas eksperimen sebesar 62,14 sedangkan kelas kontrol sebesar 61,03. Hasil ini menunjukkan bahwa kemampuan awal antara kelas eksperimen dan kelas kontrol adalah sama. Nilai median kelas eksperimen sama dengan kelas kontrol yaitu sebesar 62. Nilai modus dari kelas eksperimen sebesar 58, sedangkan kelas kontrol sebesar 68. Besarnya simpangan baku untuk kelas eksperimen sebesar 8,83, sedangkan kelas kontrol sebesar 8,30. Skor minimum untuk kelas eksperimen sebesar 44, sedangkan kelas kontrol sebesar 41. Skor maksimum untuk kelas eksperimen sama dengan kelas kontrol, yaitu 79.

Tabel 9. Uji Normalitas Soal KPS

\begin{tabular}{cccc}
\hline No & Variabel & Sig. & Keterangan \\
\hline 1 & Eksp. KPS & 0,371 & Normal \\
2 & Kont. KPS & 0,594 & Normal \\
\hline
\end{tabular}

Tabel 9 menunjukkan bahwa besarnya signifikasi untuk kelas eksperimen sebesar 0,371, sedangkan kelas kontrol sebesar 0,594. Hasil uji normalitas untuk dua kelas tersebut menggambarkan bahwa data yang diperoleh berdistribusi normal, karena nilai sig. > nilai alpha yaitu 0,05 .

Tabel 10. Uji Homogenitas Soal KPS

\begin{tabular}{cccccc}
\hline \multirow{2}{*}{ Variabel } & \multicolumn{5}{c}{ Uji F } \\
\cline { 2 - 6 } & F hitung & Df & F tabel & Sig. & Ket. \\
\hline KPS & 0,001 & $1: 70$ & 4,00 & 0,975 & Homogen \\
\hline
\end{tabular}

Tabel 10 menyajikan nilai signifikansi sebesar 0,975, sehingga dapat disimpulkan bahwa sampel berasal dari populasi yang homogen, karena nilai sig. > nilai alpha, yaitu 0,05 .
Data KPS diperoleh berdasarkan observasi di kelas kontrol dan kelas eksperimen seperti yang disajikan pada Tabel 11 dan Tabel 12.

\section{Hasil Observasi KPS}


Tabel. 11. Data Hasil Obsertvasi KPS Kelas Kontrol

\begin{tabular}{cccccccc}
\hline \multirow{2}{*}{ KPS } & \multicolumn{3}{c}{ Pertemuan } & \multirow{2}{*}{ Rerata } & \multirow{2}{*}{ Kategori } \\
\cline { 2 - 5 } & I & II & III & IV & V & & SKB \\
KPS1 & 1.00 & 1.00 & 1.00 & 1.00 & 1.00 & 1.00 & SKB \\
KPS2 & 1.00 & 1.00 & 1.00 & 1.00 & 1.00 & 1.00 & SKB \\
KPS3 & 1.00 & 1.00 & 1.00 & 1.00 & 1.00 & 1.00 & SKB \\
KPS4 & 1.00 & 1.00 & 1.00 & 1.00 & 1.00 & 1.00 & SKB \\
KPS5 & 1.00 & 1.00 & 1.00 & - & 1.00 & 1.00 & SKB \\
KPS6 & 1.00 & 1.00 & 1.00 & - & 1.00 & 1.00 & SKB \\
KPS7 & 1.00 & 1.00 & 1.00 & - & 1.00 & 1.00 & SKB \\
KPS8 & 1.00 & 1.00 & 1.00 & - & 1.00 & 1.00 & SKB \\
KPS9 & 1.00 & 1.00 & 1.00 & - & 1.00 & 1.00 & SKB \\
KPS10 & 1.00 & 1.00 & 1.00 & - & 1.00 & 1.00 & \\
\hline
\end{tabular}

Data hasil observasi keterampilan proses sains peserta didik untuk kelas kontrol dengan skor 1 yang memiliki kategori sangat kurang baik. Kondisi ini terjadi dikarenakan metode pembelajaran yang digunakan oleh pendidik pada kelas kontrol berupa metode ceramah, sehingga tidak ada keterampilan proses sains yang dilakukan siswa selama pembelajaran berlangsung.

Tabel. 12. Hasil Observasi KPS untuk Kelas Eksperimen

\begin{tabular}{cccccccc}
\hline \multirow{2}{*}{ KPS } & \multicolumn{9}{c}{ Pertemuan } & Rerata & \multirow{2}{*}{ Kategori } \\
\cline { 2 - 5 } & I & II & III & IV & V & & \\
KPS1 & 4.43 & 4.38 & 4.52 & 4.48 & 4.48 & 4.46 & SB \\
KPS2 & 3.67 & 3.95 & 3.95 & 3.86 & 3.57 & 3.80 & B \\
KPS3 & 5.00 & 4.43 & 4.38 & 3.76 & 4.43 & 4.40 & SB \\
KPS4 & 3.67 & 3.57 & 3.76 & 4.43 & 3.57 & 3.80 & B \\
KPS5 & 5.00 & 5.00 & 5.00 & - & 5.00 & 5.00 & SB \\
KPS6 & 4.67 & 4.67 & 4.62 & - & 4.48 & 4.61 & SB \\
KPS7 & 5.00 & 5.00 & 5.00 & - & 5.00 & 5.00 & SB \\
KPS8 & 4.67 & 4.67 & 4.62 & - & 4.48 & 4.61 & SB \\
KPS9 & 3.76 & 3.95 & 4.05 & - & 4.33 & 4.02 & B \\
KPS10 & 5.00 & 5.00 & 5.00 & - & 5.00 & 5.00 & SB \\
\hline
\end{tabular}

Hasil observasi ketrampilan proses sains peserta didik di kelas eksperimen pada lima kali pertemuan diperoleh data bahwa KPS untuk pertemuan 1 dengan rerata total 4,46 dengan kategori sangat baik. KPS untuk pertemuan ke 2 dengan rerata skor 3,80 dengan kategori baik. KPS pada pertemuan ke 3 dengan rerata skor 4,40 dengan kategori sangat baik. KPS untuk pertemuan ke 4 dengan rerata skor 3,80 dengan kategori baik. KPS untuk pertemuan ke 5 dengan rerata skor 5 dengan kategori sangat baik. KPS untuk pertemuan ke 6 dengan rerata skor 4,61 dengan kategori sangat baik. KPS pertemuan ke
7 dengan rerata skor 5 dengan kategori sangat baik. KPS pertemuan ke 8 dengan rerata skor 4,61 dengan kategori sangat baik. KPS untuk pertemuan ke 9 dengan rerata skor 4,02 dengan kategori baik. KPS pada pertemuan ke 10 dengan rerata skor 5,00 dengan kategori sangat baik.

\section{Keterlaksanaan RPP}

Data keterlaksanaan pembelajaran diperoleh dari setiap pertemuan di kelas eksperimen disajikan pada Tabel 13.

Tabel. 13. Keterlaksanaan Pembelajaran di Kelas Eksperimen

\begin{tabular}{cccccccccccc}
\hline \multirow{2}{*}{ No } & \multirow{2}{*}{ Aspek } & \multicolumn{2}{c}{ Pertemuan I } & \multicolumn{2}{c}{ Pertemuan II } & \multicolumn{2}{c}{ Pertemuan III } & \multicolumn{2}{c}{ Pertemuan IV } & \multicolumn{2}{c}{ Pertemuan V } \\
\cline { 3 - 11 } & Rerata & Kategori & Rerata & Kategori & Rerata & Kategori & Rerata & Kategori & Rerata & Kategori \\
\hline 1 & Pendahuluan & 0.60 & B & 0.80 & SB & 1.00 & SB & 0.60 & B & 0.80 & SB \\
2 & Kegiatan Inti & 0.91 & SB & 0.73 & B & 0.82 & SB & 1.00 & SB & 1.00 & SB \\
3 & Penutup & 0.91 & SB & 0.73 & B & 0.82 & SB & 1.00 & SB & 1.00 & SB
\end{tabular}




\section{Hasil Posttest}

Hasil posttest disajikan pada Tabel 14-21.

Tabel 14. Deskriptif Statistik Soal KPS

\begin{tabular}{cccc}
\hline No & Statistik & Eksp. KPS & Kont. KPS \\
\hline 1 & Mean & 74,78 & 65,61 \\
2 & Median & 75,00 & 65,00 \\
3 & Modus & 68,00 & 68,00 \\
4 & Simpangan baku & 7,69 & 8,36 \\
5 & Minimum & 58,00 & 51,00 \\
6 & Maksimum & 89,00 & 86,00 \\
\hline
\end{tabular}

Berdasarkan data deskriptif statistik soal KPS pada Tabel 14 dapat diperoleh informasi mengenai besarnya mean untuk kelas eksperimen, yaitu 74,78, sedangkan untuk kelas kontrol sebesar 65,61. Data ini menunjukkan adanya perbedaan skor KPS yang signifikan antara kelas eksperimen dengan kelas kontrol. Besarnya median untuk kelas eksperimen sebesar 75, sedangkan kelas kontrol sebesar 65. Modus untuk kelas eksperimen sama dengan kelas kontrol, yaitu 68. Besarnya simpangan baku untuk kelas eksperimen sebesar 7,69, sedangkan untuk kelas kontrol sebesar 8,36. Skor minimum untuk kelas eksperimen sebesar 58, sedangkan untuk kelas kontrol sebesar 51. Skor maksimum untuk kelas eksperimen sebesar 89, sedangkan untuk kelas kontrol sebesar 86.

Tabel 15. Deskriptif Statistik Angket Motivasi Belajar

\begin{tabular}{cccc}
\hline No & Statistik & Eksp. Motiv & Kont. Motiv \\
\hline 1 & Mean & 124,50 & 119,69 \\
2 & Median & 125,00 & 120,00 \\
3 & Modus & 125,00 & 120,00 \\
4 & Simpangan baku & 2,26 & 2,59 \\
5 & Minimum & 119,00 & 115,00 \\
6 & Maksimum & 128,00 & 126,00 \\
\hline
\end{tabular}

Berdasarkan data deskriptif statistik angket motivasi belajar pada Tabel 15 dapat terlihat bahwa besarnya mean untuk kelas eksperimen sebesar 124,5, sedang untuk kelas kontrol sebesar 119,69. Hasil ini menunjukkan bahwa motivasi belajar peserta didik kelas eksperimen lebih tinggi daripada kelas kontrol. Median untuk kelas eksperimen sebesar 125, sedangkan untuk kelas kontrol dengan skor 120. Modus untuk kelas eksperimen sebesar 125, sedangkan kelas kontrol sebesar 120. Besarnya simpangan baku untuk kelas eksperimen sebesar 2,26, sedangkan untuk kelas kontrol 2,59. Skor minimum untuk kelas eksperimen sebesar 119, sedangkan kelas kontrol 115. Skor maksimum untuk kelas eksperimen sebesar 128, sedangkan kelas kontrol 126.

Tabel 16. Uji Normalitas Soal KPS

\begin{tabular}{cccc}
\hline No & Variabel & Sig. & Keterangan \\
\hline 1 & Eksp. KPS & 0,626 & Normal \\
2 & Kont. KPS & 0,504 & Normal \\
\hline
\end{tabular}

Berdasarkan data uji normalitas soal KPS pada Tabel 16 dapat terlihat nilai signifikasi pada kelas eksperimen sebesar 0,626, sedangkan untuk kelas kontrol sebesar 0,504, sehingga hasil uji normalitas terhadap data dari dua kelas tersebut berdistribusi normal karena nilai sig. > nilai alpha 0,05 ).

Tabel 17. Uji Normalitas Data Motivasi Belajar

\begin{tabular}{cccc}
\hline No & Variabel & Sig. & Keterangan \\
\hline 1 & Eksp. Motiv & 0,298 & Normal \\
2 & Kont. Motiv & 0,440 & Normal \\
\hline
\end{tabular}

Hasil uji normalitas terhadap data yang diperoleh menggunakan angket motivasi belajar siswa yang tersaji pada Tabel 17 dapat diketahui bahwa nilai signifikasi untuk kelas eksperimen sebesar 0,298, sedangkan kelas kontrol sebesar 0,440. Berdasarkan hasil uji ini menunjukkan bahwa data motivasi belajar yang berasal dari dua kelas berdistribusi normal, karena nilai sig. $>$ nilai alpha, yaitu 0,05 .

Tabel 18. Uji Homogenitas Soal KPS

\begin{tabular}{cccccc}
\hline \multirow{2}{*}{ Variabel } & \multicolumn{5}{c}{ Uji F } \\
\cline { 2 - 5 } & F hitung & df & F tabel & Sig. & Ket \\
\hline KPS & 0,137 & $1: 70$ & 4,00 & 0,713 & Homogen \\
\hline
\end{tabular}

Berdasarkan data uji homogenitas soal KPS seperti yang tersaji pada Tabel 18 dapat terlihat nilai signifikansinya sebesar 0,713 . Ber- dasarkan hasil uji tersebut dapat digeneralisasi bahwa sampel diambil dari populasi yang homogen, karena nilai sig. > nilai alpha yaitu 0,05 .

Tabel 19. Uji Homogenitas Data Motivasi Belajar 


\begin{tabular}{cccccc}
\hline & F hitung & df & F tabel & Sig. & Ket \\
\hline Motivasi & 0,450 & $1: 70$ & 4,00 & 0,504 & Homogen \\
\hline
\end{tabular}

Berdasarkan uji homogenitas data motivasi belajar peserta didik seperti tersaji pada Tabel 19 terlihat bahwa nilai signifikansinya sebesar 0,504. Hasil uji homogenitas tersebut menggambarkan bahwa data motivasi belajar peserta didik memiliki variansi yang homogen, dengan nilai sig. > nilai alpha 0,05 .

Tabel 20. Uji Korelasi KPS dan Motivasi Belajar

\begin{tabular}{cccc}
\hline Variabel & $\mathbf{r}_{\text {hitung }}$ & Sig. & Ket \\
\hline KPS dengan Motivasi & 0.694 & 0,000 & Ada Korelasi \\
\hline
\end{tabular}

Data uji korelasi KPS dengan motivasi belajar siswa antara kelas eksperimen dan kelas kontrol disajikan pada Tabel 20. Hasil uji memperoleh nilai signifikansi sebesar 0,000 , sehing- ga dapat disimpulkan bahwa terdapat korelasi antara KPS dengan motivasi belajar siswa dengan nilai sig. < nilai alpha 0,05 .

Tabel 21. Data Hasil MANOVA

\begin{tabular}{ccccc}
\hline \multirow{2}{*}{ Hipotesis } & \multicolumn{3}{c}{ Uji F } & Ket \\
\cline { 2 - 5 } & $\mathbf{F}_{\text {hitung }}$ & $\mathbf{F}_{\text {tabel }}$ & Sig. & Diterima \\
$\mathrm{H}_{\mathrm{a} 1}$ & 34,615 & 3,15 & 0,00 & Diterima \\
$\mathrm{H}_{\mathrm{a} 2}$ & 23.457 & 3,15 & 0,00 & Diterima \\
$\mathrm{H}_{\mathrm{a} 3}$ & 70.176 & 3,15 & 0,00 & \\
\hline
\end{tabular}

Analisis data menggunakan Manova seperti tersaji pada Tabel 21 didasarkan pada output Hotelling's Trace untuk multivariate test. Besarnya nilai $\mathrm{F}$ yaitu 34,615 yang menunjukkan bahwa $\mathrm{F}_{\text {hitung }}$ lebih besar dari $\mathrm{F}_{\text {tabel }}(34,615$ > 3,15 ), sehingga $\mathrm{Ha}_{1}$ dinyatakan diterima. Hasil ini menggambarkan bahwa pembelajaran fisika dengan SSP berbasis pendekatan contextual teaching and learning lebih berpengaruh dibandingkan dengan perangkat pembelajaran konvensional terhadap peningkatan keterampilan proses sains dan motivasi belajar peserta didik.

Hasil uji untuk $\mathrm{H}_{\mathrm{a} 2}$ diperoleh nilai $\mathrm{F}_{\text {hitung }}$ sebesar 23,457 yang menunjukkan bahwa $F_{\text {hitung }}$ lebih besar dari $\mathrm{F}_{\text {tabel }}(23,457>3,15)$, sehingga $\mathrm{H}_{\mathrm{a} 2}$ dinyatakan diterima. Hasil analisis ini menegaskan bahwa pembelajaran fisika dengan SSP berbasis pendekatan contextual teaching and learning lebih berpengaruh dibandingkan dengan perangkat pembelajaran konvensional terhadap keterampilan proses sains peserta didik.

Hasil pengujian terhadap $\mathrm{H}_{a 3}$ diperoleh nilai $F_{\text {hitung }}$ sebesar 70,176 yang menunjukkan bahwa $\mathrm{F}_{\text {hitung }}$ lebih besar dari $\mathrm{F}_{\text {tabel }}(70,176$ > 3,15), sehingga disimpulkan bahwa $\mathrm{Ha} 3$ dinyatakan diterima. Hasil analisis ini memberi gambaran bahwa pembelajaran fisika dengan SSP berbasis pendekatan contextual teaching and learning lebih berpengaruh dibandingkan dengan perangkat pembelajaran konvensional terhadap motivasi belajar siswa.
Hasil respon peserta didik terhadap proses pembelajaran di kelas eksperimen yang diperoleh melalui angket disajikan pada Tabel 22.

Tabel 22. Respon Siswa terhadap Proses Pembelajaran

\begin{tabular}{cccc}
\hline No & Aspek & Rerata & Kategori \\
\hline 1 & Penyenggaraan & 3,10 & B \\
2 & Pembelajaran & 3,68 & SB \\
3 & KPS & 3,49 & SB \\
& Motivasi Belajar & Th & SB \\
\hline
\end{tabular}

Berdasarkan data respon siswa terhadap proses pembelajaran di kelas eksperimen sesuai Tabel 22 terlihat besarnya rerata untuk setiap aspek yang dinilai. Rerata untuk setiap aspek meliputi aspek penyelenggaraan pembelajaran sebesar 3,10 dengan kategori baik, aspek KPS memperoleh skor 3,68 dengan kategori sangat baik, serta aspek motivasi belajar memperoleh skor 3,49 dengan kategori sangat baik. Berdasarkan rerata respon siswa terhadap proses pembelajaran di kelas eksperimen sebesar 3,42 dengan kategori sangat baik.

\section{SIMPULAN DAN SARAN}

\section{Simpulan}

Berdasarkan hasil penelitian dan pembahasan dapat disimpulkan bahwa (1) SSP fisika yang terdiri dari silabus, RPP, buku siswa, LKS, dan instrumen penilaian layak digunakan dalam 
pembelajaran; (2) pembelajaran fisika menggunakan SSP berbasis pendekatan kontekstual dapat meningkatkan keterampilan proses sains siswa berdasarkan perbedaan skor pretest dan posttest untuk kelas eksperimen dari 62,14 ke 74,78 , sedangkan kelas kontrol dari 61,03 ke 65,61 . Skor gains untuk kelas eksperimen sebesar 12,64, sedangkan untuk kelas kontrol sebesar 4,58; (3) pembelajaran fisika menggunakan SSP berbasis pendekatan kontekstual dapat meningkatkan motivasi belajar berdasarkan skor motivasi belajar kelas eksperimen sebesar 124,50 yang terbukti lebih tinggi dari kelas kontrol sebesar 119,69.

\section{Saran}

Saran pemanfaatan, diseminasi, dan pengembangan produk lebih lanjut di antaranya (1) SSP fisika ini dapat dikembangkan lebih lanjut menggunakan pendekatan ataupun model pembelajaran yang lain seperti model pembelajaran inkuiri, maupun problem based learning (PBL); (2) SSP fisika ini dapat digunakan oleh guru dalam proses pembelajaran. Guru fisika juga dapat mengembangkan produk SSP fisika lebih lanjut untuk materi lain dengan langkah pengembangan yang sama; serta (3) SSP fisika yang dikembangkan diharapkan dapat didiseminasikan di sekolah lain yang lebih luas.

\section{DAFTAR PUSTAKA}

Depdiknas. (2002). Pendekatan kontekstual (Contextual Teaching and learning (CTL). Jakarta: Ditjen Dikdasmen.
Ghozali, I. (2011). Aplikasi analisis multivariat dengan program IBM SPSS 19. Semarang: Universitas Diponegoro.

Hamalik, O. (2011). Kurikulum dan pembelajaran. Jakarta: Bumi Aksara.

Kemendiknas. (2007). Peraturan Menteri Pendidikan Nasional Republik Indonesia Nomor 20 Tahun 2007 tentang Standar Penilaian Pendidikan. Diperbanyak oleh BSNP, Jakarta.

Riecher, J. (2001). Role of Technology in Contextual Teaching. Texas Technology Connection; Fall 2001; 8, 2/3; ProQuest Education Journals. Pg. 4.

Thiagarajan, S., Semmel, D.S., Semmel, M.I. (1974). Instructional development for training teachers of expectional children. Minneapolis, Minnesota: leadership training institute/special education, University of Minnesota.

Uno, H. B. (2011). Teori motivasi dan pengukurannya analisis di bidang pendidikan. Jakarta: PT Bumi Aksara.

Wilke R. R. et al. (2005). Practical advice for teaching inquiry-based science process skills in the biological sciences. The American Biology Teacher, Volume 67 No. 9. 